\title{
Woman-centered shared decision-making to promote contraceptive counseling: an integrative review
}

\author{
Tomada de decisão compartilhada centrada na mulher para promoção do aconsel hamento em anticoncepção: \\ revisão integrativa
}

Toma de decisión conjunta dirigida a la mujer para la promoción de consejo en anticoncepción: revisión integrativa

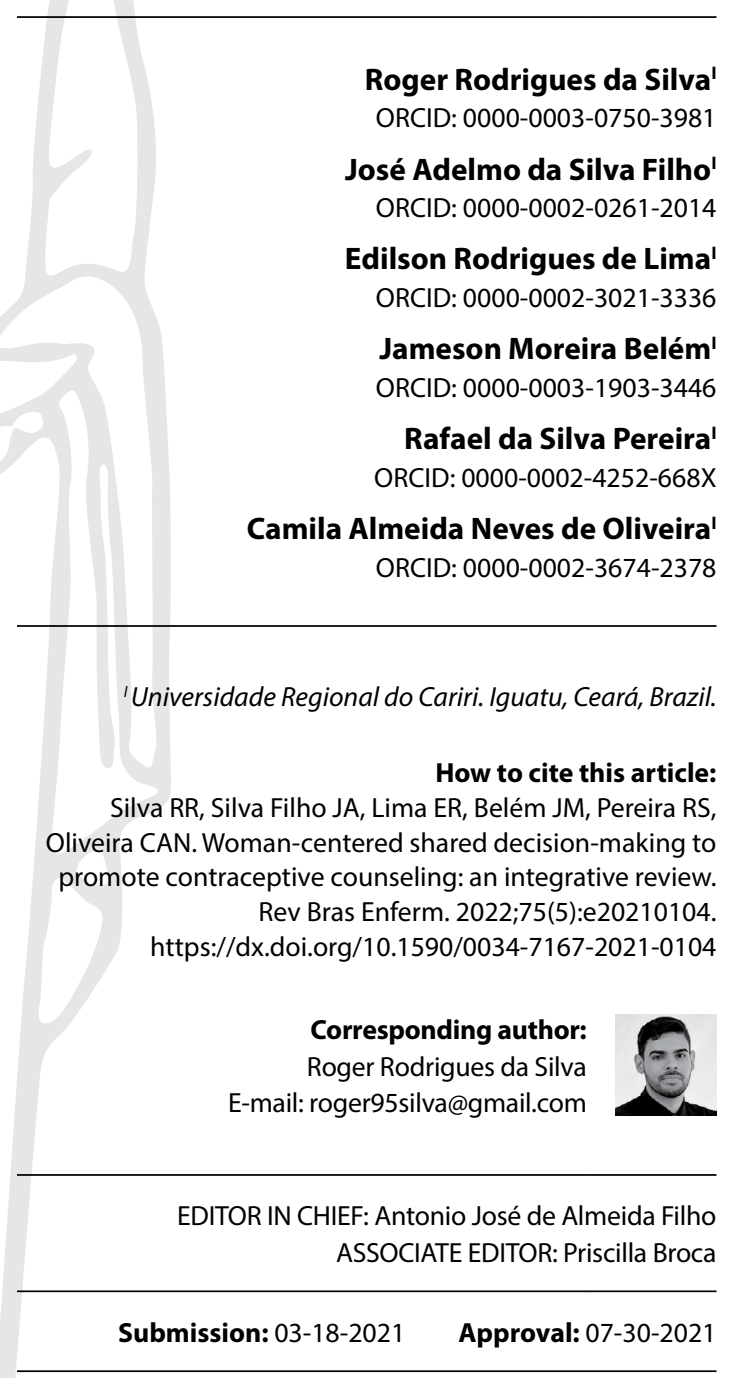

\begin{abstract}
Objective:To summarize scientific evidence on the woman-centered shared decision-making process for the promotion of contraceptive counseling. Methods: Integrative literature review with a sample of nine primary articles selected from MEDLINE via PubMed, CINAHL, Web of Science, Scopus, ScienceDirect, Embase, LILACS, and BDENF. Results: The study evidenced a comprehensive chain of segments for the development of the shared approach centered on women through counseling on contraception, fragmenting the evidence acquisition in relational elements for the choice implementation and continuation of the chosen method; systematization of consistent information for choice implementation and continuation of the method; and challenges for implementing shared decision-making. Final considerations: The process of woman shared decision-making centered during the consultation on contraception counseling favors the qualified choice and effective adherence to a contraceptive method based on the professional's clinical vision adjusted to the woman's preferences.

Descriptors: Family Planning; Shared Decision Making; Patient-Centered Care; Contraception; Counseling.
\end{abstract}

\section{RESUMO}

Objetivo: Sumarizar evidências científicas acerca do processo de tomada de decisão compartilhada centrada na mulher para promoção do aconselhamento em anticoncepção. Métodos: Revisão integrativa da literatura com amostra de nove artigos primários selecionados nas bases MEDLINE via PubMed, CINAHL, Web of Science, Scopus, ScienceDirect, Embase, LILACS e BDENF. Resultados: Evidenciou-se uma abrangente cadeia de segmentos para desenvolvimento da abordagem compartilhada centrada na mulher por meio do aconselhamento em anticoncepção, fragmentando a captação de evidências em elementos relacionais para efetivação da escolha e continuação do método escolhido; sistematização de informações consistentes para efetivação da escolha e continuação do método; e desafios para implementação da tomada de decisões compartilhada. Considerações finais: $O$ processo de tomada de decisão compartilhada centrada na mulher durante a consulta de aconselhamento em anticoncepção favorece a escolha qualificada e adesão efetiva a um método anticoncepcional com base na visão clínica do profissional ajustada às preferências da mulher.

Descritores: Planejamento Familiar; Tomada de Decisão Compartilhada; Cuidado Centrado no Paciente; Anticoncepção; Aconselhamento.

\section{RESUMEN}

Objetivo: Resumir evidencias científicas acerca del proceso de toma de decisión conjunta dirigida a mujer para promoción del consejo en anticoncepción. Métodos: Revisión integrativa de la literatura con muestra de nueve artículos primarios seleccionados en las bases MEDLINE vía PubMed, CINAHL, Web of Science, Scopus, ScienceDirect, Embase, LILACS y BDENF. Resultados: Evidenciado una abarcadora cadena de segmentos para desarrollo de estrategia conjunta dirigida a mujer mediante consejo en anticoncepción, fragmentando la captación de evidencias en elementos relacionales para efectuación de elección y continuación del método elegido; sistematización de informaciones consistentes para efectuación de elección y continuación del método; y desafíos para implementación de toma de decisiones conjunta. Consideraciones finales: El proceso de toma de decisión conjunta dirigida a mujer durante la consulta de consejo en anticoncepción favorece la elección cualificada y adhesión efectiva a un método contraceptivo basado en la visión clínica del profesional ajustada a preferencias de la mujer.

Descriptores: Planificación Familiar; Toma de Decisiones Conjunta; Atención Dirigida al Paciente; Anticoncepción; Consejo. 


\section{INTRODUCTION}

The humanization of health care has become a topic of continuous discussion nowadays, enveloping the person under care as the protagonist of the process of circumspection of their health. Patient-centered care (PCC), integrated into this modern conceptualization of humanization, aims to institute the centralization of preferences by guaranteeing the benevolence of the users regarding health promotion and maintenance ${ }^{(1)}$.

In this segment, the precept of PCC aims to respect the individual towards their needs, preferences, and individual values. Thus, the autonomy of the individual acts in consonance with the service provider since the clinical conducts must meet, above all, the values expressed by the person under care based on the shared legitimation of decisions ${ }^{(2)}$.

In the context of reproductive planning (RP), counseling in contraception is defined as a form of advice to promote access and informed choice of contraceptive methods, their correct use, and, consequently, the enhance of their pharmacological effect ${ }^{(3)}$.

Shared decision-making (SDT), a fragment belonging to PCC, consists of three steps: information sharing, deliberation, and decision-making ${ }^{(4)}$. This sequence represents a consistently ordered procedure for contraceptive counseling since it establishes adherence to women's preferences and follows with relevant information aligned with stated predispositions ${ }^{(5)}$.

However, countless problems remain to fully promote contraceptive counseling, since there are no surveillance and judgment systems that ensure the consent that the guidelines similar to the RP assert the quality of individualized counseling; furthermore, the lack of supplies, professional inexperience, and lack of interest in contraceptive consultation undermine the system and make it flawed ${ }^{(6)}$.

In view of this controversy, when the decision-sharing approach is employed in sexual and reproductive health consultations, there is a significant reduction in the aforementioned failures and, finally, consecutive progress toward the rectilinear promotion of contraceptive counseling. This interaction between the preference-centered approach and the counseling consultation allows women to enjoy a welcoming environment, with privacy/ confidentiality, social support, and autonomy regarding the choice of handling of the consultation objective ${ }^{(7)}$.

Therefore, this approach may benefit the woman who seeks RP service by conditioning the evaluation of the biopsychosocial trinomial to the promotion of counseling on contraception, based on the woman's active participation in the final choice of contraceptive.

This study is relevant because it highlights the importance of the insertion of new models that place women's preferences as a basic element for health promotion, optimizing conducts and making the user the indispensable core for the mechanism of decisions and recommendations in health.

\section{OBJECTIVE}

Summarize scientific evidence on the woman-centered shared decision-making process for promoting contraceptive counseling.

\section{METHODS}

Integrative literature review that followed six steps: 1) elaboration of the review question; 2) search and selection of primary studies; 3 ) extraction of data from the studies; 4) critical appraisal of the primary studies included in the review; 5 ) synthesis of the review results, and 6) presentation of the review ${ }^{(8)}$.

Because it is a study of a systematized methodological nature, supported by the appropriation of secondary data from the public domain, there was no need for appreciation by an ethics and research committee for its development.

At first, we identify the study question: How does woman-centered share decision-making promote contraceptive counseling for reproductive planning services users? It was formulated based on the PICO strategy, an acronym for Patient, Intervention, Comparison, and Outcomes. It is worth mentioning that, in integrative review, some elements of the PICO strategy are not always contemplated ${ }^{(8)}$ - in this case, a comparison was not applicable.

Chart 1 - PICO Strategy

\begin{tabular}{|c|c|c|}
\hline $\begin{array}{c}\text { Strategy } \\
\text { item }\end{array}$ & Components of the question & DeCS/MESH \\
\hline $\mathbf{P}$ & $\begin{array}{c}\text { Women who use reproductive } \\
\text { planning services }\end{array}$ & Women; Family Planning \\
\hline $\mathbf{I}$ & $\begin{array}{c}\text { Shared decision making between } \\
\text { woman and professional }\end{array}$ & $\begin{array}{c}\text { Decision Support; Shared } \\
\text { Decision Making }\end{array}$ \\
\hline $\mathbf{C}$ & Not applicable & Not applicable \\
\hline $\mathbf{0}$ & $\begin{array}{c}\text { Woman-Centered } \\
\text { Contraception Counseling }\end{array}$ & $\begin{array}{c}\text { Contraceptive Counseling; } \\
\text { Patient-Centred Care }\end{array}$ \\
\hline
\end{tabular}

Inclusion criteria were: original articles and published in Portuguese, English, and Spanish. For exclusion criteria: duplicate and repeated studies and those that did not fit the research object. It is noteworthy that we did not delimit a period of coverage for the inclusion of references to achieve a greater quantity of articles that dealt with the object of study of this review.

The searches were conducted in May 2020, using an advanced search tool in the following electronic databases: Medical Literature Analysis and Retrieval System Online (MEDLINE) via PubMed, Cumulative Index to Nursing and Allied Health Literature (CINAHL), Web of Science (WoS), Scopus, Science Direct, Embase, Latin American Literature on Health Sciences (LILACS) and the Nursing Database (BDENF).

For the search of eligible studies, we used controlled descriptors from the Health Sciences Descriptors (DeCS) vocabulary in Portuguese (Family Planning, Shared Decision Making, Patient-Centered Care, Contraceptive and Counseling); and the Medical Subject Heading (MeSH) vocabulary in English (Family Planning; Shared Decision Making, patient-centered Care, Contraceptive and Counseling). The interlinking of the descriptors was mediated by the Boolean AND operator. The search strategy applied to MEDLINE/PubMed was: "Family Planning" AND Contraceptive AND Counseling AND"Shared Decision Making."The key was adapted according to the specificity of each subsequent database.

Two independently reviewers screened the initial literature in the databases. After applying the search strategies, 147 
references were identified in the databases/virtual library. The achieved results were exported to the online reference manager Endnote Web. At first, duplicate references were excluded using an Endnote Web identification tool ( $n=51)$. Next, a subject screening was performed, including reading the title and abstract $(n=96)$. Subsequently, the eligible references were read in their entirety and analyzed according to the inclusion and exclusion criteria $(n=29)$. Six articles were included, whose references were manually screened for studies that addressed the research object and met the eligibility criteria. The execution of this process aimed to complement the sample for the composition of the review and recruitment of potential evidence.

There was a limitation of samples of articles due to the search systematization, criteria for selecting references, and originality of the theme. The Preferred Reporting Items for Systematic Reviews and Meta-Analyses (PRISMA) ${ }^{(9)}$ flowchart demonstrates the search and selection process, as illustrated in Figure 1.

Throughout the process, it is noteworthy that, to avoid selection biases, the analysis of primary references occurred independently by two reviewers, using as parameters the previously established criteria, and guided by the guiding question. When identified differences of opinion, a third reviewer was designated to read and issue a conclusive opinion to ensure methodological rigor to the selection and inclusion of studies.

The data was extracted by a previously developed instrument containing the variables of identification (author, title, place, and year of publication), objectives (general and specific), methodological design, sample, mainly results, outcomes and level of scientific evidence, perspectives on contraceptive counseling in the context of shared decision making, theoretical elements for implementing the preference centering approach, and main barriers to promoting care based on the precept of preference centering.

For sizing as to the level of scientific evidence, the studies were classified into seven levels: Level 1: evidence from systematic review or meta-analysis; Level 2: evidence derived from at least one well-designed randomized controlled trial; Level 3: evidence obtained from well-designed clinical trials without randomization; Level 4: evidence from well-designed cohort and case-control studies; Level 5: evidence derived from a systematic review of descriptive and qualitative studies; Level 6: evidence derived from a single descriptive or qualitative study; and Level 7: evidence from authorities opinion or experts report ${ }^{(10)}$.

The data was organized into three thematic categories in the analysis process, classified and grouped by similarity of content according to the grouping of evidence extracted in the primary studies. To this end, we used procedures recommended by the data reduction method, which consists of interpreting, coding, and transforming the raw data collected to simplify, abstract, focus, and organize in a manageable structure ${ }^{(11)}$.

The presentation of the extracted evidence occurred through the descriptive synthesis of the data and the use of image resources (table and figure) with subsequent discussion in the light of the specialized scientific literature.

\section{RESULTS}

The characterization of information from the primary studies and classification to the level of scientific evidence is in Chart 2.

The evidence extracted comprised a comprehensive chain of segments designated as fundamental to aggregate and optimize the process of contraceptive counseling consultation. The significant axes concerning the precepts of the shared approach were: (1) Relational elements between professional and woman; (2) Systematization of consistent information to processing the choice and continuation of the method; and (3) Challenges for implementing shared decision making. 
Chart 2 - Summary of the articles included in chronological order according to title, year, country, objective, method, sample, outcome, and level of evidence

\begin{tabular}{|c|c|c|c|c|c|}
\hline Title & $\begin{array}{c}\text { Year/ } \\
\text { Country }\end{array}$ & Objective & $\begin{array}{l}\text { Method/ } \\
\text { sample }\end{array}$ & Outcome & $\begin{array}{l}\text { Level of } \\
\text { Confidence }\end{array}$ \\
\hline $\begin{array}{l}\text { Nobili MP, } \\
\text { Piergrossi S, } \\
\text { Brusati V, Moja } \\
\text { EA. }{ }^{(12)}\end{array}$ & $\begin{array}{l}2007 \\
\text { Italy }\end{array}$ & $\begin{array}{l}\text { To evaluate a patient- } \\
\text { centered contraceptive } \\
\text { counseling intervention } \\
\text { on knowledge, attitudes, } \\
\text { and contraceptive use } \\
\text { in a group of Italian } \\
\text { women who requested } \\
\text { termination of pregnancy. }\end{array}$ & $\begin{array}{l}\text { Randomized } \\
\text { controlled } \\
\text { Prospective study } \\
41 \text { women }\end{array}$ & $\begin{array}{l}\text { The effect of an intervention centered on the patient } \\
\text { that explores women's feelings, attitudes, and beliefs } \\
\text { about contraception --addressing it cooperatively } \\
\text {-- allowed women to adopt more favorable attitudes } \\
\text { while choosing an effective contraceptive method } \\
\text { and presented a positive adherence towards it. }\end{array}$ & Level 2 \\
\hline $\begin{array}{l}\text { Dehlendorf C, } \\
\text { Diedrich J, Drey } \\
\text { E, Postone A, } \\
\text { Steinauer J.(13) }\end{array}$ & $\begin{array}{l}2010 \\
\text { EUA }\end{array}$ & $\begin{array}{l}\text { Provide information on } \\
\text { women's experiences } \\
\text { and preferences } \\
\text { regarding contraceptive } \\
\text { counseling, including } \\
\text { whether demographic } \\
\text { characteristics are } \\
\text { associated with the } \\
\text { decision-making style. }\end{array}$ & $\begin{array}{l}\text { Cross-sectional } \\
\text { Prospective study } \\
257 \text { women }\end{array}$ & $\begin{array}{l}\text { Demographic characteristics did not correlate } \\
\text { strongly with decision-making preferences. The } \\
\text { experiences of women receiving contraceptive } \\
\text { counseling were associated with preferences: those } \\
\text { who prefer autonomous decision-making reported } \\
\text { higher levels of satisfaction with their contraceptive } \\
\text { method and less influence from health care } \\
\text { providers on their decision. }\end{array}$ & Level 4 \\
\hline $\begin{array}{l}\text { Dehlendorf C, } \\
\text { Levy K, Kelley } \\
\text { A, Grumbach K, } \\
\text { Steinauer J.(14) }\end{array}$ & $\begin{array}{l}2013 \\
\text { EUA }\end{array}$ & $\begin{array}{l}\text { Assess patients' } \\
\text { preferences for birth } \\
\text { control counseling, } \\
\text { focusing on the decision- } \\
\text { making process, to } \\
\text { inform future efforts to } \\
\text { conceive interventions } \\
\text { of counseling to improve } \\
\text { contraceptive use. }\end{array}$ & $\begin{array}{l}\text { Qualitative } \\
\text { Prospective study } \\
42 \text { women }\end{array}$ & $\begin{array}{l}\text { A model of contraceptive counseling more consistent } \\
\text { with the shared decision-making, in which the } \\
\text { provider can be involved within limits, favors the } \\
\text { encouragement of contraceptive use and adherence. } \\
\text { In the family planning field, with a young patient } \\
\text { population related to medical assistance areas and the } \\
\text { need to consider personal and sensitive issues, patients } \\
\text { may be particularly interested in personal involvement } \\
\text { with their specialists. }\end{array}$ & Level 6 \\
\hline $\begin{array}{l}\text { Dehlendorf C, } \\
\text { Kimport K, Levy } \\
\text { K, Steinauer J. }{ }^{(15)}\end{array}$ & $\begin{array}{l}2014 \\
\text { EUA }\end{array}$ & $\begin{array}{l}\text { To report results from } \\
\text { a qualitative analysis of } \\
\text { contraceptive counseling } \\
\text { visits at clinics in the } \\
\text { San Francisco Bay Area } \\
\text { and describe providers' } \\
\text { approaches to counseling } \\
\text { and contraceptive } \\
\text { patterns in their use. }\end{array}$ & $\begin{array}{l}\text { Qualitative } \\
\text { Prospective study } \\
342 \text { women } \\
25 \text { professionals }\end{array}$ & $\begin{array}{l}\text { Three main communication approaches were } \\
\text { revealed: closed, uninformed choice, and shared } \\
\text { decision-making. Women advised to follow } \\
\text { uninformed or closed choice approaches had a little } \\
\text { discussion about what they valued in a method, and } \\
\text { their experts did not participate in the decision- } \\
\text { making process. Visits characterized by shared } \\
\text { decision-making emphasized collaborative decision- } \\
\text { making, including relationship building and } \\
\text { active facilitation of the decision-making process } \\
\text { to identify a method that best fit the woman's } \\
\text { expressed needs. }\end{array}$ & Level 6 \\
\hline $\begin{array}{l}\text { Dehlendorf } \\
\text { C, Henderson } \\
\text { JT, Vittinghoff } \\
\text { E, Grumbach } \\
\text { K, Levy K, } \\
\text { Schmittdiel J, et } \\
\text { al. }{ }^{(16)}\end{array}$ & $\begin{array}{l}2016 \\
\text { EUA }\end{array}$ & $\begin{array}{l}\text { Determine whether the } \\
\text { interpersonal quality } \\
\text { assistance during } \\
\text { contraceptive counseling } \\
\text { is associated with their } \\
\text { use over time. }\end{array}$ & $\begin{array}{l}\text { Prospective } \\
\text { longitudinal study } \\
316 \text { women } \\
38 \text { professionals }\end{array}$ & $\begin{array}{l}\text { The quality of interpersonal assistance influences } \\
\text { contraceptive use. In family planning treatment } \\
\text { specifically, objective and quality measures of } \\
\text { interpersonal assistance reported by patients } \\
\text { predicted better contraceptive use, stressing the } \\
\text { importance of interaction for contraceptive counseling. } \\
\text { A defining characteristic of patient-centered assistance } \\
\text { is emphasizing the treatment of patients as individuals, } \\
\text { including their needs and preferences }\end{array}$ & Level 4 \\
\hline $\begin{array}{l}\text { Carvajal } \\
\text { DN, Gioia D, } \\
\text { Mudafort ER, } \\
\text { Brown PB, } \\
\text { Barnet B. }^{(17)}\end{array}$ & $\begin{array}{l}2017 \\
\text { EUA }\end{array}$ & $\begin{array}{l}\text { Identify factors } \\
\text { influencing contraceptive } \\
\text { decision-making among } \\
\text { Latin American women in } \\
\text { Baltimore. }\end{array}$ & $\begin{array}{l}\text { Qualitative } \\
\text { Prospective study } \\
16 \text { women }\end{array}$ & $\begin{array}{l}\text { Participants strongly emphasized that effective } \\
\text { communication and trust with professionals are } \\
\text { crucial for decision-making. Women pointed out the } \\
\text { support in informed decision-making over which } \\
\text { contraceptive method was best for them, not which } \\
\text { methods professionals thought were best for them, } \\
\text { highlighting their autonomy of choice. }\end{array}$ & Level 6 \\
\hline $\begin{array}{l}\text { Fox E, Reyna } \\
\text { A, Malcolm } \\
\text { NM, Rosmarin } \\
\text { RB, Zapata LB, } \\
\text { Frederiksen BN, } \\
\text { et al. } \text {. }^{(18)}\end{array}$ & $\begin{array}{l}2018 \\
\text { EUA }\end{array}$ & $\begin{array}{l}\text { Summarize evidence over } \\
\text { which preferences clients } \\
\text { have for the contraceptive } \\
\text { counseling they receive. }\end{array}$ & $\begin{array}{l}\text { Systematic Review } \\
\text { Retrospective } \\
26 \text { articles } \\
\text { (10 database) }\end{array}$ & $\begin{array}{l}\text { This review included } 26 \text { articles describing } 25 \text { studies } \\
\text { related to client preferences for contraceptive } \\
\text { counseling. An increasing number of studies have } \\
\text { addressed this topic since } 2011 \text {, maintaining a growing } \\
\text { focus on patient-centeredness in healthcare in } \\
\text { general and family planning specifically. This evidence } \\
\text { suggests that to improve the patient-centeredness of } \\
\text { counseling, providers can use customized approaches } \\
\text { to elicit what information is most valuable to patients } \\
\text { and offer personalized counseling. }\end{array}$ & Level 5 \\
\hline
\end{tabular}




\begin{tabular}{|c|c|c|c|c|c|}
\hline Title & $\begin{array}{c}\text { Year/ } \\
\text { Country }\end{array}$ & Objective & $\begin{array}{c}\text { Method/ } \\
\text { sample }\end{array}$ & Outcome & $\begin{array}{l}\text { Level of } \\
\text { Confidence }\end{array}$ \\
\hline $\begin{array}{l}\text { Chen M, Lindley } \\
\text { A, Kimport K, } \\
\text { Dehlendorf C. }\end{array}$ & $\begin{array}{l}2019 \\
\text { EUA }\end{array}$ & $\begin{array}{l}\text { Explore and describe how } \\
\text { to apply shared decision } \\
\text { making in the context of } \\
\text { contraceptive counseling. }\end{array}$ & $\begin{array}{l}\text { Transversal } \\
\text { derived from a } \\
\text { cohort } \\
\text { Prospective } \\
40 \text { women } \\
24 \text { professionals }\end{array}$ & $\begin{array}{l}\text { In contraceptive counseling, the stages of sharing } \\
\text { and deliberation of information were largely } \\
\text { integrated. By leading with questions about } \\
\text { preferences, providers can explicitly acknowledge } \\
\text { those preferences, build rapport with the patient, } \\
\text { and move more efficiently through the collaborative } \\
\text { decision-making process. }\end{array}$ & Level 4 \\
\hline $\begin{array}{l}\text { Dehlendorf C, } \\
\text { Fitzpatrick J, } \\
\text { Fox E, Holt K, } \\
\text { Vittinghoff E, } \\
\text { Reed R, et al. }{ }^{(20)}\end{array}$ & $\begin{array}{l}2019 \\
\text { EUA }\end{array}$ & $\begin{array}{l}\text { To evaluate the effect of } \\
\text { My Birth Control on the } \\
\text { preventative continuation } \\
\text { of the contraceptive } \\
\text { treatment experience } \\
\text { and quality of decision } \\
\text { making. }\end{array}$ & $\begin{array}{l}\text { Cluster Controlled } \\
\text { Randomized } \\
\text { Prospective } \\
758 \text { women } \\
28 \text { professionals }\end{array}$ & $\begin{array}{l}\text { There was no observation of an effect of My Birth } \\
\text { Control on the primary outcome of contraceptive } \\
\text { continuation or outcomes related to a method of } \\
\text { choice and unintended pregnancy. However, a positive } \\
\text { impact of this decision support tool was documented } \\
\text { on several patient-centered outcomes, including } \\
\text { experiences in contraceptive counseling, decision } \\
\text { quality, and knowledge of contraceptive options. }\end{array}$ & Level 2 \\
\hline
\end{tabular}

\section{Relational elements between professional and patient}

At first, relational topics were listed to determine a good fluency of the relationship between professionals and women. Evaluating attitudes, beliefs, desires, and fears ${ }^{(12-13,15)}$ represented a primordial behavior for the perfect welcoming of the woman. In this process, the specialist offers cooperation ${ }^{(13)}$, trust, qualified listening, patience ${ }^{(18)}$, and confidentiality/privacy ${ }^{(17)}$ to establish the woman's credibility about counseling.

The essential elements were solid, practical, positive, accessible, considerate communication, and free of complex technical terms. With this, the process for the woman's adherence to the consultation became feasible, taking into account the accessibility of clear and concise information to her understanding ${ }^{(16-19)}$.

The interpersonal relationship with professionals also topped the list of elements essential for women's comfort during counseling. A friendly conversation represents an excellent way to establish trust and make women more open about their wishes and insecurities about the desired methods ${ }^{(14-20)}$.

Five articles emphasized the importance of not neglecting the woman's preferences during the counseling process; and enhanced the need for implementing that view in the counseling process, establishing these predilections as to the basis for optimal sequencing of counseling ${ }^{(13,15,17-19)}$.

\section{Systematization of consistent information for choice implementation and continuation of the method}

Many studies have addressed the seriousness of promoting informed counseling. Assessing the woman's prior knowledge about the desired contraceptive method favored recognizing the level of education on the subject and investigating the real reasons that led her to choose it ${ }^{(12,15)}$.

After screening the woman's interests and jointly deciding which method to adopt, other matters were addressed, like issues regarding the mechanism of action, recommendations for use ${ }^{(18-19)}$, potential risks, efficacy for birth control ${ }^{(17-20)}$, and other detailed instructions about the contraceptive ${ }^{(18)}$.

Three studies revealed in their results that women seek subsidies in supplementary tools, to incorporate knowledge prior to the consultation on the desired contraceptive and complement information during and after the consultation, beyond the verbalization ${ }^{(14)}$ that comes from the professional to the woman. They listed informative technologies on methods, such as brochures and catalogs ${ }^{(14,18)}$; and virtual technologies, such as cellular apps ${ }^{(20)}$.

The discussion of side effects resulting from the methods was widely questioned in six studies ${ }^{(14-15,17-20)}$. These results determined that the explanation about adverse effects rarely or never happened during the consultations for consensus on the final choice, therefore the problem directly interfered with adherence after recognizing adverse symptoms ${ }^{(14-15,17-20)}$.

Based on the description of the elements, it was possible to distinguish them among attributions essentially motivated by the professional (evaluate attitudes, beliefs, desires, fears ${ }^{(12-13,15)}$, qualified listening, patience ${ }^{(18)}$, confidentiality/privacy ${ }^{(17)}$, accessible and attentive communication, accessibility of clear information $^{(16-19)}$, evaluate preferences ${ }^{(13,15,17-19)}$, informed counseling ${ }^{(12,15)}$ and mutual attributions (solid, effective, positive communication $^{(16-19)}$, cooperation ${ }^{(13)}$, trust $^{(18)}$, interpersonal relationship ${ }^{(14-20)}$ for development conducive to the contraception counseling consultation.

\section{Challenges for implementing shared decision-making}

All primary studies which were included addressed SDT; however, until the implementation of that approach, other types of decisions were found. The autonomous decision corresponded to the woman's search for the counseling service. The professional had a role only in the prescription of the method and its brief explanation, but the final decision rested solely with the woman. Another proportion distinguished the preference for the method led only by the professional. The latter was a preference among low-income women or those with insufficient knowledge about contraceptive guidelines ${ }^{(13,15,20)}$.

The other type of decision included the professional's opinion as important to exemplify the range of methods available in the system and their implications for reproductive life. In the same sense, the women wanted the provider to be involved in the technical point of view of their previous clinical experiences but not to take a coercive position, delegating the final decision always to the woman ${ }^{(14,18-19)}$. 
The lack of interest in engaging with the professional was justified in two articles due to prejudice, generating discomfort noticed among black, Latina, and low-income women, for identifying domineering, oppressive, and restrictive behavior, in which the main goal for the professional was birth control, not taking into account the preferences and experiences of women. This bias contributed to a high rate of abandonment of contraceptive treatment after the consultation ${ }^{(17-18)}$.

Given the evidence extinguishing biases for counseling effectiveness, it was observed that the segments described supporting the distinction of a woman-centered shared decision-making approach for the integral promotion of effective contraceptive counseling. Based on the integration of all the elements above, Figure 2 presents, using a Research Onion Framework model, the foundational layers for the full development of counseling consultation, subject to the projection of the principle of woman-centered shared decision-making approach.

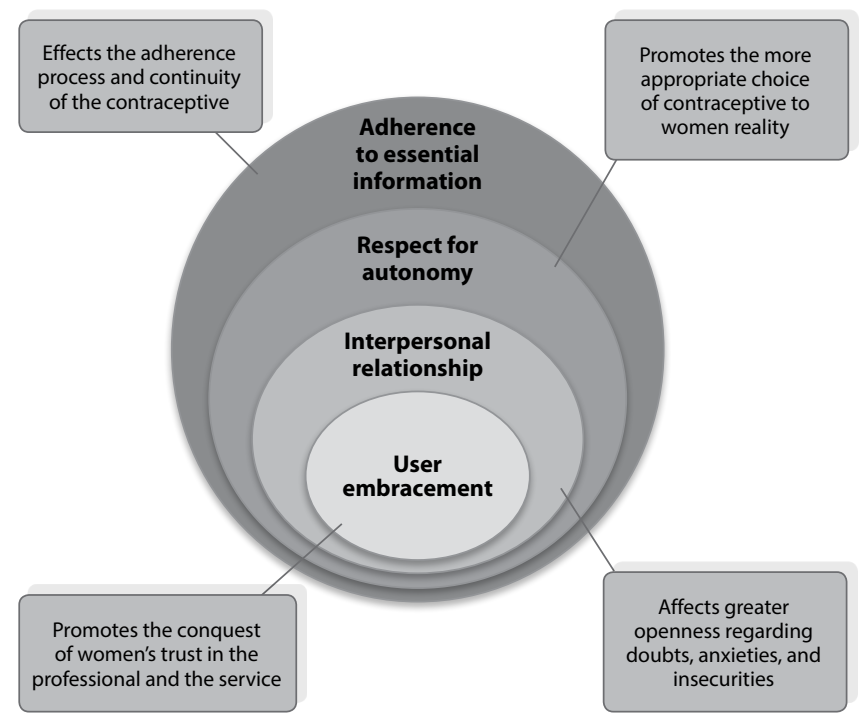

Figure 2 - Distinguishing stages for contraceptive counseling based on women-centered shared decision-making precepts

\section{DISCUSSION}

The body of evidence analyzed allowed us to synthesize the essential parts for the decision-making centered on women favors the integrated development of contraceptive counseling. At first, relational elements emerged as the gateway to gaining women's trust. Professional adherence to technologies before, during, and after the consultation proved to be a strong driver for the woman's autonomy and reliability in the service. The SDT demonstrated to be a much sought-after method for planned contraceptive counseling, effective and aligned to women's preferences.

Still, it is necessary to ground characteristics of social coexistence to achieve the fullness of counseling based on the perspective of centralization of preferences. It is possible to realize that the necessary constituents for such effectiveness correspond to the progress of relational attitudes between the professional and the woman, analysis and adherence of collected aspirations, and finalization of the joint contraceptive choice ${ }^{(21-22)}$.
The initial choice of the contraceptive could be a cumulative journey of experiences; the woman herself creates a particular scientific foundation based on personal and family experiences and media influence ${ }^{(23-24)}$, adjusted to her principles and values ${ }^{(25)}$. Therefore, it is impossible to apply an identical counseling standard for heterogeneous audiences ${ }^{(26)}$.

To get to the target of the woman's intentions, the professional should induce the conversation, after the reception, with direct questions about the goals and preferences for the counseling in question. After receiving the feedbacks, the process must continue in a personalized way, tending specifically to the purpose previously asked ${ }^{(14,18,27)}$.

The shared decision about the types of women's preferences - implying that their wishes ranged from the efficacy of the method for birth control, adoption of long-lasting reversible contraception capable of curbing amenorrhea, valuing the frequency of predictable monthly cycles, and sterilization ${ }^{(27)}$ emphasizes that the preference for a particular method is not simply about preventing unplanned pregnancy.

Subsequently to the determination of the method, research points to the seriousness in addressing information essential to the understanding of women about the mechanics related to the contraceptive. It must emphasize that the elucidation of mechanisms of action, adverse effects, and absorption of doubts should be broad and patiently inserted in the context of instructive counseling ${ }^{(6,23-25,28-30)}$.

Incorporation of clarifications should occur in a way adapted to the doubts and interests of women; in addition to verbalization, there should be the inclusion of instruments for the realization of understanding. Information technologies (printed or digital) contribute to elucidating incorrect perceptions about methods or favor informed choice before interaction with the professional. The professional and the service neglect the adaptation of these resources to improve counseling to women, starting with those professionals who do not incisively address the notions about contraceptives ${ }^{(31)}$.

The neglect of professionals in talking about the side effects triggered by each method should be the object of ponderation because it is shown as a strong determinant for the choice of method and is directly associated with the point of motivation for adherence of contraceptive treatment ${ }^{(6,24-25,28,30)}$.

The coercive approach performed by the professional during counseling consultations on contraception sets up an embarrassment directed to women. It imposes directive decisions on which methods are best for the users, without evaluating their preferences and decisions, aiming primarily at birth control, which corrupts the integrality of the concept of a woman-centered shared decision-making approach ${ }^{(24-25,27-28,30,32-33)}$.

Regardless of the barriers related to the promotion of reproductive health, especially about contraception counseling, it is inferred, based on the evidence analyzed, that the shared approach focused on women's preferences subsidizes the systematization of behaviors for resolving biases concerning the consultation of contraception counseling, maintaining strong influence for the process of joint decision and effectiveness of contraceptive treatment. 


\section{Study limitations}

The limitations of this article refer to the reduced sample of studies, considering that the descriptors used for crossreferencing and searching the databases and virtual libraries were very precise to the area in question, not being sufficiently favorable for more comprehensive recruitment. Another limitation is attributed to the eligibility criteria regarding the inclusion of references published only in Portuguese, English, and Spanish.

\section{Contributions to the field of nursing in contraceptive counseling}

In the context of promoting counseling, the nurse leads the provision of contraceptive services. Thus the adequate assimilation of this approach to contraceptive counseling would facilitate the process of recommendations and informed choice, favoring adherence to the legitimized method and reducing excessive waste of resources and capital in health systems.

\section{FINAL CONSIDERATIONS}

This review highlighted that the process of shared decisionmaking centered on women during consultation about contraceptive counseling favors the qualified choice and effective adherence to a contraceptive method based on a professional's view adjusted to the woman's preferences. Once the principles of user embracement, interpersonal relationships, respect for autonomy, and informed promotion about the method are employed, it establishes the conditions for adherence to the jointly defined contraceptive, favoring the women well-being concerning contraceptive treatment.

Thus, this study is significant for detailing the mechanics of this approach for timely development in contraceptive counseling and the field of sexual and reproductive health. In this regard, it contributes to the implementation of clinical care based on evidence-based practice, promotion of health education, respect for women's sexual and reproductive rights, and continuing nurse education.

\section{REFERENCES}

1. Rodrigues JLSQ, Portela MC, Malik AM. Agenda para a pesquisa sobre o cuidado centrado no paciente no Brasil. Ciênc Saúde Coletiva. 2019;24(11):4263-4273. https://doi.org/10.1590/1413-812320182411.04182018

2. Dehlendorf C, Henderson JT, Vittinghoff E, Steinauer J, Hessler D. Development of a patient-reported measure of the interpersonal quality of Family planning care. Contraception. 2018;97:34-40. https://doi.org/10.1016/j.contraception.2017.09.005

3. Berardi MC, Mendes-Rodrigues C, Paro HBMS. Contraceptive counseling lectures do not influence decision making in family planning services. Ciênc Saúde Coletiva. 2020;25(6):2369-2376. https://doi.org/10.1590/1413-81232020256.26472018

4. Charles C, Gafni A, Whelan T. Shared decision-making in the medical encounter: what does it mean? (Or it takes at least two to tango). Soc Sci Med. 1997;44(5):681-92. https://doi.org/10.1016/S0277-9536(96)00221-3

5. Dehlendorf C, Krajewski C, Borrero S. Contraceptive counseling: best practices to ensure quality communication and enable effective contraceptive use. Clin Obstet Gynecol. 2014;57(4):659-673. https://doi.org/10.1097/GRF.0000000000000059

6. Bitzer J, Marin V, Lira J. Contraceptive counseling and care: a personalized interactive approach. Eur J Contracept Reprod Health Care. 2017;22(6):418-23. doi:10.1080/13625187.2017.1414793

7. Diamond-Smith N, Warnock R, Sudhinaraset M. Interventions to improve the personcentered quality of family planning services: a narrative review. Reprod Health. 2018;15(144). https://doi.org/10.1186/s12978-018-0592-6

8. Mendes KDS, Silveira RCCP, Galvão CM. Revisão integrativa: método de pesquisa para a incorporação de evidências na saúde e na enfermagem. Texto Contexto Enferm. 2008;17(4):758-64. https://doi.org/10.1590/\$0104-07072008000400018

9. Moher D, Liberati A, Tetzlaff J, Altamn DG, The Prisma Group. Preferred reporting items for systematic reviews and meta-analyses: the PRISMA statement. Int J Surg. 2009;8:336-341. https://doi.org/10.1371/journal.pmed.1000097

10. Melnyk BM, Fineout-Overholt E. Evidence-based practice in nursing and health: a guide to best practice -2 nd ed. Philadelphia: Wolters Kluwer; Lippincott Williams \& Wilkins Health; 2011.

11. Whittemore R, Knafl K. The integrative review: updated methodology. J Adv Nurs. 2005;52(5):546-553. https://doi.org/10.1111/j.1365-2648.2005.03621.x

12. Nobili MP, Piergrossi S, Brusati V, Moja EA. The effect of patient-centred contraceptive counseling in women who undergo a voluntary termination of pregnancy. Patient Educ Couns. 2007;65(3):361-368. https://doi.org/10.1016/j.pec.2006.09.004

13. Dehlendorf C, Diedrich J, Drey E, Postone A, Steinauer J. Preferences for decision-making about contraception and general health care among reproductive age women at an abortion clinic. Patient Educ Couns. 2010;81(3):343-348. https://doi.org/10.1016/j.pec.2010.06.021

14. Dehlendorf C, Levy K, Kelley A, Grumbach K, Steinauer J. Women's preferences for contraceptive counseling and decision making. Contraception. 2012;88(2):250-6. https://doi.org/10.1016/j.contraception.2012.10.012

15. Dehlendorf C, Kimport K, Levy K, Steinauer J. A qualitative analysis of approaches to contraceptive counseling. Perspect Sex Reprod Health. 2014;46(4):233-240. https://doi.org/10.1363/46e2114

16. Dehlendorf $\mathrm{C}$, Henderson JT, Vittinghoff $\mathrm{E}$, Grumbach K. Association of the quality of interpersonal care during family planning counseling with contraceptive use. Am J Obstet Gynecol. 2016;215(1):78.E1-78.E9. https://doi.org/10.1016/j.agog.2016.01.173 
17. Carvajal DN, Gioia D, Mudafort ER, Brown PB, Barnet B. How can primary care physicians best support contraceptive decision making? A qualitative study exploring the perspectives of Baltimore Latinas. Women's Health Inssues. 2017;27(2):158-66. https://doi.org/10.1016/j. whi.2016.09.015

18. Fox E, Reyna A, Malcolm NM, Rosmarin RB, Zapata LB, Frederiksen BN, et al. Client preferences for contraceptive counseling: a systematic review. Am J Prev Med. 2018,55(5):691-702. https://doi.org/10.1016/j.amepre.2018.06.006

19. Chen M, Lindley A, Kimport K, Dehlendorf C. An in-depth analysis of the use of shared decision making in contraceptive counseling. Contraception. 2018;99(3):187-191. https://doi.org/10.1016/j.contraception.2018.11.009

20. Dehlendorf C, Fitzpatrick J, Fox E, Holt K, Vittinghoff E, Reed R, et al. Cluster randomized trial of a patient-centred contraceptive decision support tool, My Birth Control. Am J Obstet Gynecol. 2019;220(6):565.E1-565.E-12. https://doi.org/10.1016/j.ajog.2019.02.015

21. Holt K, Zavala I, Quintero X, Mendoza D, McCormick MC, Dehlendorf C, et al. Women's preferences for contraceptive counseling in Mexico: results from a focus group study. Reprod Health. 2018;15(128):2-11. https://doi.org/10.1186/s12978-018-0569-5

22. Holt K, Dehlendorf C, Langer A. Defining quality in contraceptive counseling to improve measurement of individuals' experiences and enable service delivery improvement. Contraception. 2017;96(3):133-137. https://doi.org/10.1016/j.contraception.2017.06.005

23. Downey MM, Arteaga S, Villaseñor E, Gomez AM. More than a destination: contraceptive decision making as a journey. Women's Health Inssues. 2017;27(5):539-545. https://doi.org/10.1016/j.whi.2017.03.004

24. Marshall C, Kandahari N, Raine-Bennett T. Exploring young women's decisional needs for contraceptive method choice: a qualitative study. Contraception. 2017;97(3):243-248. https://doi.org/10.1016/j.contraception.2017.10.004

25. Holt K, Reed R, Crear-Perry J, Scott C, Wulf S, Dehlendorf C. Beyond same-day long-acting reversible contraceptive access: a person-centred framework for advancing high-quality, equitable contraceptive care. Am J Obstet Gynecol. 2019;222(4):S878.E1-S878.E6. https://doi. org/10.1016/j.ajog.2019.11.1279

26. Politi MC, Estlund A, Milne A, Buckel CM, Peipert JF, Madden T. Barriers and facilitators to implementing a patient-centred model of contraceptive provision in community health centers. Contracept Reprod Med. 2016;1(21). https://doi.org/10.1186/s40834-016-0032-3

27. Rivlin K, Isley MM. Patient-centred contraceptive counseling and prescribing. Clin Obstet Gynecol. 2018;61(1):27-39. https://doi. org/10.1097/GRF.0000000000000337

28. Brandi $K$, Fuentes $L$. The history of tiered-effectiveness contraceptive counseling and the importance of patient-centred family planning care. Am J Obstet Gynecol. 2019;222(4):873-877. https://doi.org/10.1016/j.ajog.2019.11.1271

29. Booth K, Sundstrom B, DeMaria AL, Dempsey A. A qualitative analysis of postpartum contraceptive choice. J Commun Healthc. 2018;11(3):215-222. https://doi.org/10.1080/17538068.2018.1477445

30. Sundstrom B, Szabo C, Dempsey A. "My body. My choice": a qualitative study of the influence of trust and locus of control on postpartum contraceptive choice. J Health Commun. 2018;23(2):162-169. https://doi.org/10.1080/10810730.2017.1421728

31. Holt K, Kimport K, Kuppermann M, Fitzpatrick J, Steinauer J, Dehlendorf C. Patient-provider communication before and after implementation of the contraceptive decision support tool My Birth Control. Patient Educ Couns. 2020;103(2):315-320. https://doi.org/10.1016/j.pec.2019.09.003

32. Bryant AG, Lyerly AD, DeVane-Johnson S, Kistler CE, Stuebe AM. Hormonal contraception, breastfeeding and bedside advocacy: the case for patient-centred care. Contraception. 2019;99(2):73-76. https://doi.org/10.1016/j.contraception.2018.10.011

33. Gomez AM, Wapman M. Under (implicit) pressure: young black and Latina women's perceptions of contraceptive care. Contraception. 2017;96(4):221-6. https://doi.org/10.1016/j.contraception.2017.07.007 